\title{
Management of symptomatic intra-alveolar mid-root fracture with displaced and infected apical fragment
}

\author{
Lynn Lilly Varghese (D) ,' Auric Bhattacharya (D) ,' Gourav Kumar Sahu, ${ }^{3}$ \\ Shivani Consul ${ }^{4}$
}

${ }^{1}$ Department of Conservative Dentistry and Endodontics, Melaka Manipal Medical College, Bukit Baru, Melaka, Malaysia

${ }^{2}$ Oral and Maxillofacial Surgery, Melaka Manipal Medical College, Bukit Baru, Melaka, Malaysia

${ }^{3}$ Department of Conservative Dentistry and Endodontics, All India Institute of Medical Sciences-Bhubaneswar, Bhubaneswar, Orissa, India ${ }^{4}$ RajaRajeswari Dental College and Hospital, Bangalore, Karnataka, India

Correspondence to Dr Lynn Lilly Varghese; lynn.varghese@manipal.edu.my

Accepted 1 February 2021

\section{DESCRIPTION}

A 32-year-old male patient reported to clinic with a chief complaint of pain along with recurrent bouts of bad taste and swelling in the upper front tooth region for a year. Dental history revealed that the patient sustained trauma 10 years ago. On clinical examination, teeth \#11 and \#21 were tender on percussion without any mobility or periodontal pathosis. A draining sinus tract was present on the buccal attached gingiva of tooth \#11. Both teeth \#11 and \#21 showed no response to electric pulp testing. Since root fracture lines are usually oblique in the buccolingual direction, periapical radiographs were taken from multiple angulations of $45^{\circ}, 90^{\circ}$ and $110^{\circ} .{ }^{12}$ Radiograph of tooth \#11 revealed a root fracture at the junction of middle and apical third, blunting and loss of lamina dura of the coronal segment and substantial mesial displacement of the apical fragment. Sinus tracing was done in which the gutta percha cone stopped against the apical fragment. There were radiolucencies in relation to the apical fragment of tooth \#11, the neoapex of tooth \#11 and periapex of tooth \#21 suggestive of chronic periapical abscesses (figure 1A). Even though Cone Beam Computed Tomography (CBCT) was not done in this case, it is reported to provide high-quality 3D images which are valuable in detecting root fractures and associated alveolar socket fractures if present. ${ }^{3}$ The sensitivity of CBCT images for the detection of root fractures is $89.5 \%$, which is much higher than that of radiographs $(26.3 \%){ }^{4}$

Since the apical fragment was established as a possible proponent of periapical infection, the treatment plan comprised of the endodontic treatment of the coronal segment with an apical barrier using Biodentine followed by surgical removal of the apical fragment on tooth \#11 and endodontic treatment on tooth \#21. Anaesthesia was achieved using 2\% Lignocaine with epinephrine via buccal

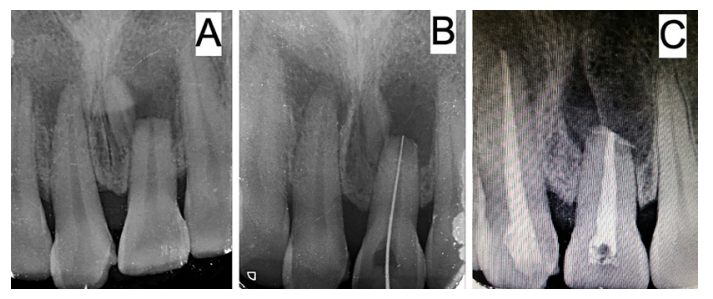

Figure 1 (A) Preoperative Intra Oral Peri-Apical radiograph showing the fractured and mesially displaced apical fragment. (B) Working length determination. (C) Postobturation radiograph.

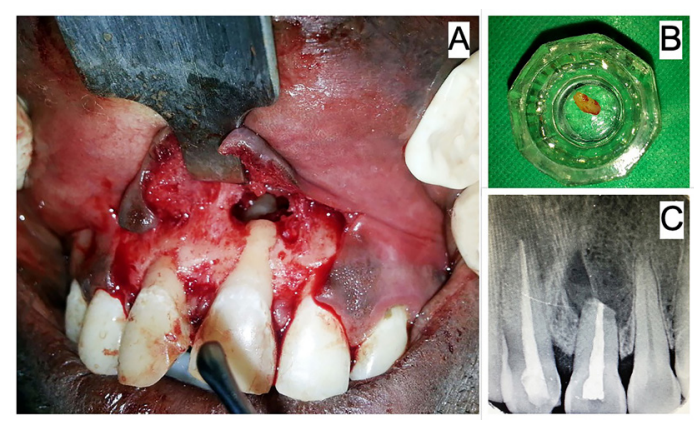

Figure 2 (A) Intraoperative view—raised mucoperiosteal flap revealing depleted buccal cortical plate along with the displaced apical fragment in situ. (B) Fractured apical fragment removed. (C) Follow-up after 1 year showing satisfactory healing.

infiltration. Rubber dam was placed, access cavity preparation was done on teeth \#11 and \#21. Working lengths were determined (figure 1B). Biomechanical preparation was completed using $\mathrm{K}$ files in step-back technique up to apical file size of \#60 along with $2.5 \%$ sodium hypochlorite and saline for irrigation. Canals were dried and compacted with calcium hydroxide intracanal medicament and the patient was recalled after 1 week. The putty-like Biodentine mix was carried into the root canal with an amalgam carrier and compacted into the apex of \#11 using hand pluggers in increments to form an apical plug of 4-5 mm thickness. The remaining root canal was obturated with thermoplasticised gutta percha and the access

\section{Patient's perspective}

By the time I approached the dental specialist for my treatment, it was already over a year that I was having issues with my front teeth. I also had pain for which I used to take pain killers. The pus and bad smelling mouth almost prevented me from talking to people normally since I was always anxious about bad breath. I was explained the entire treatment steps thoroughly. The surgery was done after which it healed well and I did not have much discomfort as much as I had anticipated. After the treatment, I was completely free of all the issues I had. It was a great relief from the dirty taste and bad breath bouts. Also, I have been completely pain free since then. I am really thankful to the dental specialist and her team for the exceptional treatment experience. 


\section{Learning points}

It is important to know that in most cases of infected teeth with fractured roots, only the coronal segment requires endodontic treatment because the pulp in the apical fragment is usually unaffected and does not become necrotic.

- In cases of root fractures, it is rare for an apical fragment to get infected; thus, it becomes imperative to diagnose it correctly and provide treatment options which is either root canal treatment of both the coronal segment and the apical fragment or root canal treatment of the coronal segment followed by the surgical removal of the apical fragment, which was done in this case.

- Various retrograde root filling materials are used in creation of an apical plug including GIC, MTA, biodentine, bioaggregate, endosequence root repair material among many others.

cavity was restored. Tooth \#21 was obturated using cold lateral condensation technique with $\mathrm{AH}$ plus sealer (figure 1C).

In the following visit after 1 week, apical fragment was surgically removed. Anaesthesia was achieved using 2\% lignocaine with epinephrine via buccal infiltration and nasopalatine nerve block. A full thickness mucoperiosteal flap was raised from tooth \#22 to tooth \#12. The buccal cortical plate in relation to tooth
\#11 was resorbed. Granulation tissue was curetted to expose the displaced apical fragment (figure 2A). The apical fragment was removed (figure $2 \mathrm{~B}$ ). The bony cavity was debrided and the flap was sutured back. One year follow-up showed complete resolution of symptoms and satisfactory healing (figure 2C).

Twitter Gourav Kumar Sahu @Drgouravsahu

Contributors LLV was responsible in diagnosis, treatment plan and treatment of patient. $A B$ contributed to treatment and follow-up of patient. GKS contributed in preparing manuscript. SC helped in editing and final proof reading of manuscript.

Funding The authors have not declared a specific grant for this research from any funding agency in the public, commercial or not-for-profit sectors.

Competing interests None declared.

Patient consent for publication Obtained.

Provenance and peer review Not commissioned; externally peer reviewed.

\section{ORCID iDs}

Lynn Lilly Varghese http://orcid.org/0000-0002-7490-9984

Auric Bhattacharya http://orcid.org/0000-0002-0108-327X

\section{REFERENCES}

1 Cohen S, Burns RC. Pathways of the pulp: Mosby St. Louis, 1998.

2 Avsever H, Gunduz K, Orhan K, et al. Comparison of intraoral radiography and conebeam computed tomography for the detection of horizontal root fractures: an in vitro study. Clin Oral Investig 2014;18:285-92.

3 Abbott PV. Diagnosis and management of transverse root fractures. Dent Traumatol 2019;35:333-47.

4 Wang P, Yan XB, Lui DG, et al. Detection of dental root fractures by using cone-beam computed tomography. Dentomaxillofac Radiol 2011;40:290-8.

Copyright 2021 BMJ Publishing Group. All rights reserved. For permission to reuse any of this content visit

https://www.bmj.com/company/products-services/rights-and-licensing/permissions/

BMJ Case Report Fellows may re-use this article for personal use and teaching without any further permission.

Become a Fellow of BMJ Case Reports today and you can:

- Submit as many cases as you like

- Enjoy fast sympathetic peer review and rapid publication of accepted articles

- Access all the published articles

Re-use any of the published material for personal use and teaching without further permission

Customer Service

If you have any further queries about your subscription, please contact our customer services team on +44 (0) 2071111105 or via email at support@bmj.com.

Visit casereports.bmj.com for more articles like this and to become a Fellow 